\title{
PERSEPSI NASABAH TERHADAP PELAYANAN FRONTLINER (STUDI KASUS PADA BPR TLM)
}

\begin{abstract}
The objective of the study about "Persepsi Nasabah Terhadap Pelayanan Frontliner (Studi Kasus Pada BPR $T L M)$ " is to determine the effect of custumer perceptions based on attitude, motivation, and past experience on frontline service in BPR TLM. This study is using quantitative descriptive approach. This study is using primary data in the form of questionnaire distributed to 100 customers who made transaction at BPR TLM and also using accidental sampling method. The result of the questionnaire regarding frontliner services wer anayzed by multiple linear regression. The result shows that customer perceptions based on attitude, motivation and past experience have significant possitive effect on frontliner services on BPR TLM. This is caused fronliner services is in line with customer's expectations, which is shown by officer fronliner attitude who are friendly and can serve customer's needs well. The comfort waitng room and fashion style of the officer make the customers feel that frontliner services in BPR TLM is good.
\end{abstract}

\begin{abstract}
ABSTRAK: Penelitian yang berjudul Persepsi Nasabah Terhadap Pelayanan Frontliner (Studi Kasus Pada BPR TLM) ini bertujuan untuk mengetahui pengaruh persepsi nasabah berdasarkan sikap, motivasi dan pengalaman masa lalu terhadap pelayanan frontliner pada BPR TLM. Penelitian ini menggunakan pendekatan deskriptif kuantitatif. Data yang digunakan adalah data primer melalui kuesioner yang dibagikan kepada 100 nasabah yang melakukan transaksi di BPR TLM dengan menggunakan metode accidental sampling dan mendapatkan 100 responden atau sampel. Hasil kuesioner yang diperoleh dari nasabah mengenai pelayanan frontliner dengan menggunakan alat analisis regresi linear berganda. Hasil penelitian ini menunjukkan bahwa persepsi nasabah berdasarkan sikap, motivasi dan pengalaman masa lalu berpengaruh signifikan positif dan signifikan terhadap pelayanan frontliner pada BPR TLM. Hal ini dikarenakan pelayanan frontliner sudah sesuai dengan harapan nasabah baik itu ditunjukkan dari sikap petugas frontliner BPR TLM yang ramah dan dapat melayani kebutuhan nasabah dengan baik dan cepat serta kenyamanan ruang tunggu dan penampilan rapi dan bersih petugas frontliner BPR TLM menjadikan nasabah merasa pelayanan frontliner pada BPR TLM sudah baik.
\end{abstract}

Eldalivia Y. Sooai ${ }^{1}$, Paulina Y. Amtiran ${ }^{2}$, Rolland E. Fanggidae ${ }^{3}$ 1,2,3 Fakultas Ekonomi Dan

Bisnis

Universitas Nusa Cendana Kupang, Nusa Tenggara Timur E-mail: eldalivia11@gmail.com

Keywords: Motivation, Frontliner Services, Experience, Customer's Perception, Attitude

Kata Kunci: Motivasi, Pelayanan Frontliner, Pengalaman, Persepsi Nasabah, Sikap 


\section{PENDAHULUAN}

\subsection{Latar Belakang}

Perkembangan usaha di Indonesia dewasa ini, telah diwarnai dengan berbagai macam persaingan pada segala bidang, sehingga setiap perusahaan harus mampu bertahan hidup bahkan harus dapat terus berkembang. Berkembangnya suatu perusahaan dapat ditentukan dari baik atau tidaknya pelayanan jasa dan produk yang diberikan. Pelayanan adalah kegiatan pemberian jasa dari satu pihak kepihak lainya. Pelayanan yang baik adalah pelayanan yang dilakukan secara ramah tamah, adil, cepat, tepat, dan dengan etika yang baik sehingga memenuhi kebutuhan dan kepuasan bagi yang menerimanya (Hasibuan, 2001:152).

Baik tidaknya pelayanan jasa dan produk yang diberikan dapat diukur melalui persepsi dari konsumen mengenai pelayanan itu sendiri. Persepsi merupakan segala proses pemilihan, pengorganisasian dan penginterprestasian masukan informasi, sensasi yang diterima melalui penglihatan, perasaan, pendengaran, penciuman dan sentuhan untuk menghasilkan makna (Fadila dan Lestari, 2013:4). Persepsi setiap orang terhadap suatu objek itu berbedabeda, oleh karena itu persepsi mempunyai sifat subyektif. Persepsi seorang akan berbagai stimulus (bentuk fisik atau komunikasi verbal) yang diterimanya dipengaruhi oleh karakteristik yang dimilikinya (Sutisna, 2001:63).

Salah satu bidang yang perkembangannya semakin pesat adalah perbankan. Menurut UU No. 10 tahun 1998 Perbankan adalah segala sesuatu yang menyangkut tentang bank, mencakup kelembagaan, kegiatan usaha, serta cara dan proses dalam melaksanakan kegiatan usahanya. Semakin berkembangnya berbagai poduk dan pelayanan jasa dari perbankan dan adanya teknologi komunikasi dan informasi yang semakin canggih, memungkinkan transaksi dan pelayanan jasa dan produk perbankan dapat dilakukan dengan cepat dan mudah (Hasibuan, 2011:155).

Kegiatan ekonomi perbankan selalu mengalami persaingan yang semakin ketat. Dalam menghadapi situasi tersebut, maka perusahaan perbankan harus mengetahui produktivitas, profitabilitas, dan kualitas pelayanan yang diberikan kepada para nasabah. Meningkatnya intensitas persaingan dan jumlah pesaing juga menuntut setiap perusahaan perbankan untuk selalu memperhatikan kebutuhan dan keinginan nasabah serta berusaha memenuhi apa yang perusahaan harapkan dengan cara yang lebih memuaskan daripada yang diberikan perusahaan pesaing (Tjiptono, 2005: 49).

Dalam usahanya untuk menarik dan mempertahankan nasabah, Bank-bank melakukan berbagai strategi untuk menarik calon nasabah agar menempatkan dananya pada bank tersebut, salah satu strategi yang dilakukan adalah meningkatkan pelayanan yang baik untuk para nasabah. Pelayanan sangat penting bagi suatu perusahaan untuk mencapai suatu tujuan. Pelayanan yang baik akan memberikan kesan positif bagi nasabah atau pelanggan. Sebaliknya, pelayanan yang buruk akan memberikan kesan yang negatif bagi pelanggan (Tjiptono, 2011:376).

Untuk melakukan pelayanan dan berhadapan serta berhubungan langsung dengan nasabah merupakan tugas dari para frontliner. Seorang frontliner dituntut untuk dapat memberikan informasi dengan jelas kepada pelanggan. Selain itu, seorang frontliner harus berpenampilan menarik dan sopan, karena merupakan cermin dan citra perusahaan. Karyawan frontliner juga dituntut untuk selalu memberikan kesan terbaik kepada pelanggan, memiliki pegetahuan produk yang baik, berpenampilan menarik, selalu 
mendengarkan kebutuhan pelanggan, mampu bekerja bersama dengan tim maupun bekerja sendirian, memiliki kemampuan berkomunikasi yang baik dan jelas (Umaya, 2009:15).

Bank Perkreditan Rakyat Tanaoba Lais Manekat (BPR TLM) sebagai salah satu BPR yang ada di kota Kupang juga dituntut untuk memberikan pelayanan terbaik bagi masyarakat. BPR TLM berdiri sejak tahun 2008 yang didirikan oleh yayasan TLM. BPR TLM memiliki kurang lebih 12.458 ini, tentunya telah memiliki kepercayaan dari nasabah-nasabahnya. Produk-produk yang diberikan BPR TLM kepada nasabahnya terdiri dari dana (tabungan dan deposito) dan kredit (konsumtif,mikro,modal kerja dan investasi) serta jasa lainnya. Selain produk dan jasa yang diberikan, terdapat fasilitas yang menunjang, seperti fasilitas kredit dengan bunga yang rendah dan pinjaman kredit yang mudah dengan syarat yang gampang dipenuhi oleh nasabah.

Produk-produk keuangan yang ditawarkan BPR TLM telah banyak dimanfaatkan oleh nasabah. Hal ini tidak terlepas dari pelayanan yang diberikan BPR TLM kepada nasabah (TLM foundation,2018). Berdasarkan laporan neraca periode Maret 2018, BPR TLM memiliki total aset sebesar Rp 219.439.277-, (OJK, 2018). Saat ini BPR TLM memiliki 1 Kantor Cabang di Kabupaten Kupang dan 1 Kantor Kas dengan jam kerja karyawan dari jam 08.00 sampai jam 17.00 untuk hari senin sampai jumat (BPR TLM, 2018). Berikut jumlah frontliner yang ada di BPR TLM sebagai berikut:
Tabel 1.1 Jumlah frontliner pada BPR TLM

\begin{tabular}{|c|c|c|}
\hline No & Frontliner & Jumlah \\
\hline 1 & Teller & 8 \\
\hline 2 & Customer Service & 5 \\
\hline 3 & Security & 12 \\
\hline \multicolumn{2}{|c|}{ Total } & 25 \\
\hline
\end{tabular}

Sumber: BPR TLM,2018

Berdasarkan pra penelitian yang dilakukan peneliti, jumlah karyawan frontliner seperti pada tabel diatas, memiliki perannya masing-masing. Dari jam kerja antara jam 08.00 hingga 17.00 , waktu tersibuk bagi petugas frontliner adalah berkisar antara 09.00 hingga 11.00. Untuk teller, dari 2 atau 3 petugas yang ada, biasanya yang aktif untuk melayani transksi nasabah adalah 1 atau 2 petugas saja, karena biasanya salah satu dari teller tersebut melakukan perhitungan uang yang masuk atau keluar dan dalam satu hari teller dapat melayani nasabah berkisar 30-60 nasabah dalam 1 jam.

Untuk customer service, dalam satu hari customer service dapat melayani nasabah berkisar 20-40 nasabah dalam 1 jam. Untuk security di bagi ke dalam shift, ada yang bertugas menjaga dari pagi hingga siang, ada yang bertugas dari siang hingga malam, dan ada yang bertugas menjaga dari malam hingga kembali pagi. Selain itu, setiap kali bertugas, ada security yang menjaga bagian pintu masuk dan ada security yang menjaga bagian luar gedung dan tempat parkir.

Berdasarkan uraian di atas, maka penulis tertarik untuk meneliti mengenai pelayanan yang diberikan oleh BPR TLM melalui persepsi nasabah dengan mengambil penelitian yang berjudul "Pengaruh Persepsi Nasabah Terhadap Pelayanan Frontliner (Studi Kasus Pada BPR TLM)".

\subsection{Rumusan Masalah}


1. Apakah pengaruh persepsi nasabah berdasarkan sikap terhadap pelayanan frontliner pada BPR TLM?

2. Apakah pengaruh persepsi nasabah berdasarkan motivasi terhadap pelayanan frontliner pada BPR TLM?

3. Apakah pengaruh persepsi nasabah berdasarkan pengalaman masa lalu terhadap pelayanan frontliner pada BPR TLM?

\subsection{Tujuan Penelitian}

1. Untuk mengetahui pengaruh persepsi nasabah berdasarkan sikap terhadap pelayanan frontliner pada BPR TLM.

2. Untuk mengetahui pengaruh persepsi nasabah berdasarkan motivasi terhadap pelayanan frontliner pada BPR TLM.

3. Untuk mengetahui pengaruh persepsi nasabah berdasarkan pengalaman masa lalu terhadap pelayanan frontliner pada BPR TLM.

\subsection{Manfaat Penelitian}

1. Bagi Pengembangan Ilmu Pengetahuan, hasil penelitian ini dapat memberikan wawasan dan pengetahuan tambahan bagi perguruan tinggi.

2. Bagi BPR TLM, semoga memberi manfaat bagi bank yang bersangkutan dalam memberikan pelayanannya kepada masyarakat

3. Bagi penelitian lanjutan dapat dijadikan bahan perbandingan dan bahan-bahan diskusi penelitian selanjutnya.

\section{PENGEMBANGAN HIPOTESIS}

\subsection{Kajian Teoritis}

\subsubsection{Konsep Persepsi}

\section{Pengertian Persepsi}

Istilah persepsi memiliki banyak definisi yang dikemukakan oleh para ahli, diantaranya seperti yang dikemukakan oleh Sutisna (2001:63) yang menyatakan persepsi adalah proses bagaimana stimulus-stimulus yang mempengaruhi tanggapan-tanggapan itu diseleksi dan diinterpretasikan. Persepsi setiap orang terhadap suatu objek itu berbeda-beda, oleh karena itu persepsi mempunyai sifat subyektif. Stimulus adalah setiap bentuk fisik atau komunikasi verbal yang dapat mempengaruhi tanggapan individu. Salah satu stimulus yang penting yang dapat mempengaruhi perilaku nasabah adalah lingkungan (sosial dan budaya) karena persepsi setiap orang terhadap suatu objek akan berbeda-beda, oleh karena itu persepsi mempunyai sifat subjektif. Persepsi seorang nasabah akan berbagai stimulus yang diterimanya di pengaruhi oleh karakteristik yang dimilikinya.

Berdasarkan berbagai pendapat para ahli diatas mengenai persepsi, maka dapat disimpulkan bahwa persepsi merupakan penilaian atau pemahaman seseorang atau individu terhadap sesuatu yang sama dan menghasilkan pemikiran dan pendapat yang berbeda-beda.

\section{Sifat yang Dapat Mempengaruhi Persepsi}

Menurut Nugroho (2003:164) sifat-sifat yang dapat mempengaruhi persepsi yaitu sebagai berikut:

a. Sikap

Merupakan poin yang dapat mempengaruhi positif atau negatifnya tanggapan yang akan diberikan seseorang.

b. Motivasi

Motif merupakan hal yang mendorong seseorang mendasari sikap dan tindakan yang dilakukannya.

c. Pengalaman Masa Lalu

Pengalaman masa lalu dapat mempengaruhi persepsi seseorang karena biasanya akan menarik kesimpulan yang sama dengan apa yang pernah dilihat dan didengar.

d. Minat

Merupakan faktor lain yang membedakan penilaian seseorang terhadap suatu hal atau 
objek tertentu, yang mendasari kesukaan ataupun ketidaksukaan terhadap objek tersebut.

e. Harapan

Mempengaruhi persepsi seseorang dalam membuat keputusan, seseorang akan cenderung menolak gagasan, ajakan, atau tawaran yang tidak sesuai dengan apa yang diharapkan.

f. Sasaran

Sasaran dapat mempengaruhi penglihatan yang akhirnya akan mempengaruhi persepsi.

g. Situasi

Situasi atau keadaan disekitar kita atau di sekitar sasaran yang kita lihat akan turut mempengaruhi persepsi. Sasaran atau benda yang sama yang dilihat dalam situasi yang berbeda akan menghasilkan persepsi yang berbeda pula.

\section{Faktor-Faktor Yang Mempengaruhi Persepsi}

Menurut Rahmat (2003:55) membagi faktor-faktor yang menentukan persepsi dibagi menjadi dua yaitu sebagai berikut:

a. Faktor fungsional

Faktor fungsional adalah faktor yang berasal dari kebutuhan, pengalaman masa lalu dan hal-hal lain yang termasuk apa yang disebut sebagai faktor-faktor personal.

b. Faktor struktural

Faktor struktural adalah faktor-faktor yang berasal semata-mata dari sifat stimulus fisik terhadap efek-efek syaraf yang ditimbulkan pada sistem saraf individu.

\subsubsection{Konsep Pelayanan}

\section{Pengertian Pelayanan}

Pelayanan adalah merupakan suatu proses, proses tersebut menghasilkan suatu produk yang berupa pelayanan, yang kemudian diberikan kepada pelanggan. Pelayanan menurut Kamus Besar Bahasa Indonesia (KBBI) adalah sebagai suatu usaha untuk membantu menyiapkan atau mengurus apa yang diperlukan orang lain. Menurut Hasibuan (2001:152) pelayanan adalah kegiatan pemberian jasa dari satu pihak kepihak lainya.

Sedangkan menurut Moenir (2010:26) pelayanan adalah kegiatan yang dilakukan oleh seseorang atau sekelompok orang dengan landasan faktor materi melalui sistem, prosedur dan metode tertentu dalam rangka usaha memenuhi kepentingan orang lain sesuai dengan haknya.

Berdasarkan berbagai pendapat para ahli diatas mengenai pelayanan, maka dapat disimpulkan bahwa pelayanan merupakan suatu kegiatan pemberian jasa dari satu pihak ke pihak lainnya untuk memenuhi kebutuhan, contohnya seperti dari pihak bank kepada nasabah untuk memenuhi kebutuhan yang diinginkan.

\section{Dimensi Pelayanan}

Menurut Parasuraman (2006:157) baik tidaknya suatu pelayanan dirangkum menjadi 5 dimensi pokok, yaitu sebagai berikut:

a. Bukti Langsung (Tangible), meliputi fasilitas fisik, perlengkapan, pegawai, dan sarana komunikasi.

b. Keandalan (Realibility), yakni kemampuan memberikan pelayanan yang dijanjikan dengan segera, akurat, dan memuaskan.

c. Daya Tanggap (Responsiviness), yaitu keinginan para staf dan karyawan untuk membantu para pelanggan dan memberikan pelayanan dengan tanggap.

d. Jaminan (Assurance), mencakup pengetahuan, kemampuan, kesopanan, dan sifat dapat dipercaya yang dimiliki para staf, bebas dari bahaya, resiko atau keraguraguan.

e. Empati (Emphaty), meliputi kemudahan dalam melakukan hubungan, komunikasi yang baik, perhatian pribadi, dan memahami kebutuhan para pelanggan.

\section{Dasar-dasar Pelayanan}


Menurut Kasmir (2006:18-21) dasardasar pelayanan yang harus dipahami dan dimengerti adalah sebagai berikut:

a. Berpakaian dan berpenampilan rapi dan bersih

b. Percaya diri, bersikap akrab dan penuh senyum.

c. Menyapa dengan lembut dan berusaha menyebutkan nama jika sudah kenal.

d. Tenang, sopan, hormat, serta tekun mendengarkan setiap pembicaraan.

e. Berbicara dengan bahasa yang baik dan benar.

f. Bergairah dalam melayani nasabah dan tunjukan kemampuanya.

g. Jangan menyela atau memotong pembicaraan.

h. Mampu meyakinkan nasabah serta memberikan kepuasan.

i. Jika tidak sanggup menangani permasalahan yang ada, minta bantuan.

j. Bila belum dapat melayani, beritahukan kapan akan dilayani.

\subsubsection{Bank}

\section{Pengertian Bank}

Bank berasal dari kata italia Banco yang artinya bangku. Bangku inilah yang dipergunakan bankir untuk melayani kegiatan operasionalnya kepada para nasabah. Istilah bangku secara resmi dan popular menjadi bank (Hasibuan,2011:1). Bank adalah badan usaha yang kekayaannya terutama dalam bentuk aset keuangan (financial assets) serta bermotifkan profit dan juga sosial, jadi bukan hanya keuntungan saja (Hasibuan, 2003:2)..

Sementara itu, menurut Kasmir (2012:23) Bank adalah perusahaan yang bergerak dalam bidang keuangan, artinya aktivitas perbankan selalu berkaitan dalam bidang keuangan. Dimana kegiatan utamanya adalah menghimpun dana dari masyarakat dan menyalurkannya kembali dana tersebut ke masyarakat serta memberikan jasa bank lainnya. Sedangkan menurut Undang-Undang Republik Indonesia No.10 tahun 1998 tentang Perbankan Bank adalah badan usaha yang menghimpun dana dari masyarakat dalam bentuk simpanan dan menyalurkannya kepada masyarakat dalam bentuk kredit dan/atau bentuk-bentuk lainnya dalam rangka meningkatkan taraf hidup rakyat banyak.

Dari beberapa pengertian diatas, maka dapat disimpulkan bahwa Bank merupakan badan usaha dalam bidang keuangan yang kegiatan utamanya yaitu menghimpun dana masyarakat (funding), menyalurkannya dalam bentuk kredit (lending), serta memberikan jasa pelayanan kepada masyarakat.

\section{Fungsi Bank}

Bank sebagai lembaga keuangan mempunyai fungsi utama yaitu sebagai penghimpun dana dalam bentuk pinjaman. Tetapi sebenarnya fungsi bank dapat dijelaskan dengan lebih spesifik seperti yang diungkapkan oleh Susilo, Triandaru, \& Santoso (2006:9), yaitu sebagai berikut:

\section{a. Agent of Trust}

Dasar utama kegiatan perbankan adalah kepercayaan (trust), baik dalam hal penghimpunan dana maupun penyaluran dana.

\section{b. Agent of Development}

Kegiatan perekonomian masyarakat di sektor moneter dan di sektor rill tidak dapat dipisahkan. Kedua sektor tersebut selalu berinteraksi dan saling mempengaruhi.

\section{c. Agent of Service}

Selain menghimpun dan menyalurkan dana, bank juga memberikan penawaran jasa-jasa perbankan yang lain kepada masyarakat.

\section{Jenis Bank \\ a. Bank Umum}

Bank Umum menurut UU No.10 Tahun 1998 yaitu bank yang melaksanakan kegiatan usaha secara konvensional dan/atau 
berdasarkan Prinsip Syariah yang dalam kegiatannya memberikan jasa dalam lalu lintas pembayaran.

Kegiatan-kegiatan usaha yang dapat dilakukan oleh Bank Umum yaitu:

1) Menghimpun dana dari masyarakat dalam bentuk simpanan berupa deposito berjangka, tabungan, dana atau bentuk lainnya yang dipersamakan dengan itu;

2) Menerbitkan surat pengakuan utang;

3) Menerima pembayaran atas tagihan surat berharga dan melakukan perhitungan dengan atau antar pihak ketiga.

\section{b. Bank Perkreditan Rakyat (BPR)}

Bank Perkreditan Rakyat menurut UU No.10 Tahun 1998, yaitu sebagai bank yang melaksanakan kegiatan usaha konvensional dan atau berdasarkan Prinsip Syariah yang dalam kegiatannya tidak memberikan jasa lalu lintas pembayaran. Tugas dari Badan Perkreditan Rakyat meliputi: Adapun fungsi BPR adalah sebagai berikut (Manurung \& Rahardja,2004):

1) Memberi pelayanan perbankan kepada masyarakat yang sulit atau tidak memiliki akses ke bank umum;

2) Membantu pemerintah mendidik masyarakat dalam memahami pola nasional agar ekselarasi pembangunan di sektor pedesaan dapat lebih dipercepat;

3) Menciptakan pemerataan kesempatan berusaha terutama bagi masyarakat pedesaan;

4) Mendidik dan mempercepat pemahaman masyarakat terhadap pemanfaatan lembaga keuangan formal sehingga terhindar dari jeratan rentenir.

Kegiatan usaha yang diperkenankan bagi BPR secara umum adalah sebagai berikut :

1) Menghimpun dana dari masyarakat dalam bentuk simpanan berupa deposito berjangka, tabungan dan atau bentuk lainnya yang dipersamakan dengan itu;
2) Memberikan kredit;

3) Menyediakan pembiayaan dan penempatan dana berdasarkan prinsip syariah;

4) Menempatkan dananya dalam bentuk SBI, deposito berjangka, sertifikat deposito, dan atau tabungan pada bentuk lain.

Menurut Undang-Undang Perbankan No.7 tahun 1992, kegiatan atau usaha yang dilarang bagi BPR adalah :

1. Menerima simpanan berupa giro dan ikut serta dalam lalu lintas pembayaran;

2. Melakukan kegiatan usaha dalam bentuk valuta asing;

3. Melakukan usaha perasuransian.

\subsubsection{Frontliner}

\section{Pengertian Frontliner}

Menurut Kasmir (2000:216) Frontliner adalah orang yang langsung berhadapan atau berhubungan dengan pelanggan (konsumen) atau dapat juga diartikan sebagai barisan paling depan dari suatu perusahaan, yang merupakan sebuah kategori dan bukan sebuah jabatan yang terdiri dari customer service, teller dan security.

\section{a. Customer service}

Pengertian customer service secara umum adalah setiap kegiatan yang diperuntukan atau ditujukan untuk memberikan kepuasan kepada nasabah, melalui pelayanan yang dapat memenuhi keinginan dan kebutuhan nasabah.

b. Teller

Teller adalah petugas bank yang bertanggung jawab untuk menerima simpanan, mencairkan cek, dan memberikan jasa pelayanan perbankan lain kepada masyarakat, tanda tangan pengesahan kasir diperlukan sebagai tanda sah suatu dokumen transaksi. 


\section{c. Security}

Satuan Pengamanan atau sering juga disingkat Satpam adalah satuan kelompok petugas yang dibentuk oleh instansi/proyek/badan usaha untuk melakukan keamanan fisik (physical security) dalam rangka penyelenggaraan keamanan swakarsa di lingkungan kerjanya.

\subsection{Kajian Empirik}

Penelitian-penelitian terdahulu yang dijadikan sebagai bahan referensi dalam penelitian ini adalah :

Penelitian yang dilakukan oleh Santika (2016) bertujuan untuk mengkaji persepsi nasabah Bank Perkreditan Rakyat terhadap kualitas pelayanan perbankan terutama produk tabungannya. Hasil dari penelitian ini bahwa Variabel reliability, keandalan produk perbankan BPR dan karyawan BPR dalam menjelaskan produk dinilai cukup. Sedangkan keandalan karyawan BPR dalam memberikan pelayanan dinilai masih kurang jika dibandingkan dengan karyawan bank umum, Variabel responsiveness ketanggapan karyawan BPR dalam melayani nasabah dinilai sudah baik, tetapi ketanggapan karyawan BPR dalam penyelesaian keluhan nasabah dinilai masih kurang, Variabel assurance, jaminan atas kerahasian transaksi, kebenaran proses pencatatan transaksi, dan jaminan atas produk BPR dinilai sudah baik, Variabel empathy sikap empati karyawan BPR dalam melayani dan membantu penyelesaian masalah perbankan nasabah dinilai sudah baik dan Variabel tangible, kelayakan ruangan, fasilitas pelayanan, dan keberadaan BPR dinilai belum baik. Sedangkan pemuktahiran teknologi perbankan dinilai sudah dilaksanakan oleh BPR.

Penelitian Juairiah (2016), Tujuan utama penelitian ini adalah untuk menentukan hubungan antara layanan dengan kepuasan nasabah bank Sumsel babel Syari'ah yang memilih bank tersebut sebagai tempat untuk pengelolaan keuangan keluarga. Implikasi penelitian ini adalah pihak Bank Sumsel Babel Syari'ah cabang Palembang hendaknya dapat memberikan rangsangan-rangsangan atau stimuli-stimuli dalam bentuk layanan yang lebih banyak dan berarti bagi karyawan, sehingga karyawan tersebut dapat lebih meningkatkan kepuasan nasabah dan juga profit bagi karyawan.

\subsection{Kerangka Berpikir}

Persepsi tiap nasabah mengenai pelayanan berbeda-beda tergantung dengan karakteristiknya masing-masing, dan sesuai dengan pelayanan yang diterima nasabah dari frontliner. Berdasarkan uraian diatas maka kerangka berpikir penulis sebagai berikut:

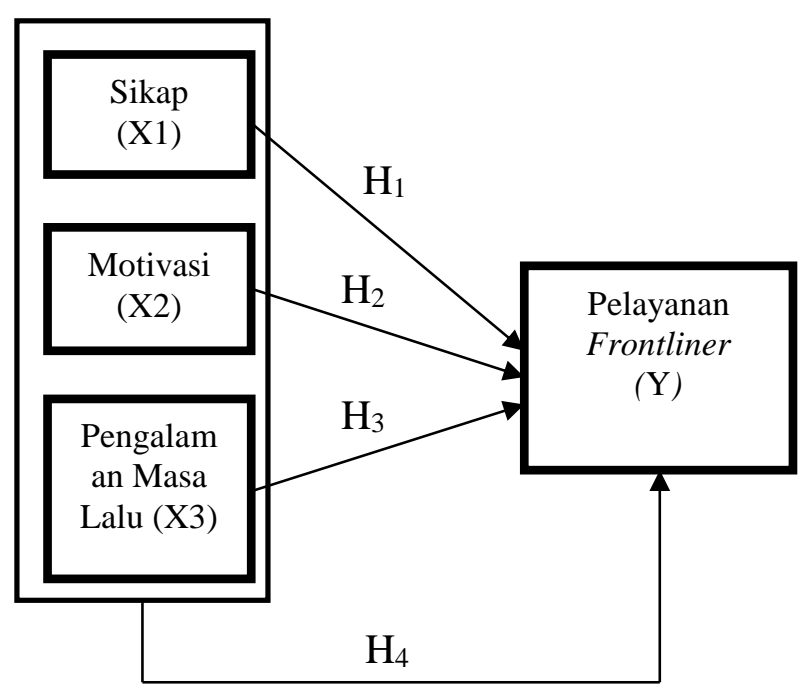

Sumber : Hasil Olah Data (2018)

\section{Gambar 2.1 Kerangka Berpikir}

\subsection{Hipotesis}

Menurut Parasuraman, Zeithaml \& Berry (2006:19) untuk mengukur baik tidaknya pelayanan diketahui dengan melakukan perbandingan antara pelayanan yang dirasakan 
(persepsi) konsumen (nasabah) dengan pelayanan yang diharapkan konsumen (nasabah). Jika pelayanan yang dirasakan sama atau melebihi pelayanan yang diharapkan maka pelayanan dikatakan atau dipersepsikan berkualitas dan memuaskan, namun apabila yang terjadi sebaliknya, maka pelayanan tersebut dikatakan atau dipersepsikan negatif atau tidak berkualitas.

Berdasarkan masalah yang telah dikemukakan, maka hipotesis dalam penelitian ini yaitu:

1. $\mathrm{H}_{\mathrm{a}}$ : Persepsi nasabah berdasarkan sikap berpengaruh terhadap pelayanan frontliner BPR TLM

2. $\mathrm{H}_{\mathrm{a}}$ : Persepsi nasabah berdasarkan motivasi berpengaruh terhadap pelayanan frontliner BPR TLM

3. $\mathrm{H}_{\mathrm{a}}$ : Persepsi nasabah berdasarkan pengalaman masa lalu berpengaruh terhadap pelayanan frontliner BPR TLM

4. $\mathrm{H}_{\mathrm{a}}$ : Persepsi nasabah berdasarkan sikap, motivasi dan pengalaman masa lalu berpengaruh terhadap pelayanan frontliner BPR TLM

\section{METODE, DATA, dan ANALISIS}

\subsection{Pendekatan Penelitian}

Penelitian ini menggunakan pendekatan penelitian deskriptif kuantitatif. Penelitian ini diartikan sebagai suatu penelitian yang berusaha mendeskripsikan suatu fenomena atau peristiwa sistematis sesuai dengan apa adanya.

\subsection{Jenis dan Sumber Data}

1. Jenis Data

Dalam penelitian ini peneliti menggunakan data kualitatif adalah data yang berupa tulisan atau data informasi yang berbentuk kalimat verbal mengenai tingkah laku manusia yang dapat diamati (Sutopo \& Arief, 2010:48), yaitu data berupa pendapat dari nasabah BPR TLM yang berinteraksi langsung dengan frontliner.
2. Sumber Data

Dalam penelitian ini peneliti menggunakan data primer dan data sekunder:

a. Data primer adalah data yang dikumpulkan oleh peneliti langsung dari sumber pertama diperoleh langsung dari BPR TLM melalui kuesioner yang dibagikan.

b. Data Sekunder adalah data yang diperoleh melalui media perantara atau tidak secara tidak langsung yang berupa buku, catatan, bukti yang telah ada, atau arsip baik yang dipublikasikan maupun tidak.

\subsection{Teknik Analisis Data}

Teknik analisis data menggunakan analisis deskriptif kuantitatif, data tersebut diperoleh dan dianalisis dengan dasar teori yang ada sehingga memberikan suatu gambaran yang cukup jelas. Adapun untuk keperluan analisis maka ditetapkan langkah-langkah sebagai berikut:

1. Menganalisis respon nasabah BPR TLM mengenai pelayanan frontliner melalui penyebaran kuesioner.

2. Menganalisis data hasil Kuesioner yang diperoleh dari nasabah mengenai pelayanan frontliner dengan menggunakan alat analisis regresi linear berganda.

Dari teknik analisis ini, akan digunakan beberapa Pengujian:

\section{Uji Validitas}

Uji validitas digunakan untuk mengukur valid tidaknya suatu Kuesioner. Suatu kuesioner dikatakan valid apabila pertanyaan pada kuesioner mampu untuk mengungkapkan sesuatu yang diukur oleh kuesioner tersebut (Gozali, 2005:160). Uji validitas dilakukan dengan membandingkan nilai $r$ hitung dengan nilai $r$ tabel untuk degree of freedom $(f)=n-2$ dengan alpha 0,05 dan $\mathrm{n}$ menunjukkan jumlah responden. Jika $r$ hitung lebih besar dari $r$ tabel dannilai $r$ positif, maka butir atau pertanyaan 
tersebut dikatakan valid.

\section{Uji Reliabilitas}

Suatu Kuesioner dikatakan reliabel atau handal jika jawaban seseorang terhadap pertanyaan adalah konsisten atau stabil dari waktu ke waktu. Uji Reliabilitas adalah tingkat kestabilan suatu alat pengukur dalam mengukur suatu gejala atau kejadian. Koefisien Alpha Crombach adalah suatu alat analisis penilaian keandalan dari suatu skala yang dibuat. Cara ini menghitung korelasi skala yang dibuat dengan seluruh variabel yang ada, dengan angka koefisien yang dapat diterima diatas 0,6-0,7 (Silalahi,2017:470).

\section{Analisis Regresi Linear Berganda}

Peneliti melakukan analisis terhadap data yang telah diuraikan dengan menggunakan metode kuantitatif, dimana variabel $\mathrm{X}_{1}$ (sikap), $\mathrm{X}_{2}$ (motivasi) dan $\mathrm{X}_{3}$ (pengalaman masa lalu) dan dipasangkan dengan data variabel $\mathrm{Y}$ (pelayanan frontliner) yang dikumpulkan melalui kumpulan data dari BPR TLM yang akan diolah dengan menggunakan uji statistik.

Dalam menganalisis data, peneliti menggunakan alat analisis regresi linear berganda. Analisis regresi linear berganda adalah alat analisis yang digunakan untuk meramalkan bagaimana keadaan (naik turunnya) variabel dependent, bila dua atau lebih variabel independent sebagai faktor prediktor dimanipulasi (dinaik turunkan nilainya). Peneliti menggunakan model analisis regreasi linear berganda (Sugiyono, 2014:277) dengan formula :

$$
\mathrm{Y}=\mathrm{a}+\mathrm{b} 1 . \mathrm{X} 1+\mathrm{b} 2 . \mathrm{X} 2+\mathrm{b} 3 . \mathrm{X} 3+
$$

Keterangan:

$$
\begin{aligned}
Y= & \text { Pelayanan frontliner } \text { (Variabel } \\
& \text { dependen/nilai yang diprediksikan) } \\
X_{1}= & \text { Sikap (Variabel independen) } \\
X_{2}= & \text { Motivasi Variabel independen }) \\
X_{3}= & \text { Pengalaman masa lalu } \\
& \text { Variabel } \text { independen })
\end{aligned}
$$

$$
\begin{aligned}
& a=\text { Konstanta (nilaiY' apabila } \mathrm{X}=0 \\
& \mathrm{~b} 1, \mathrm{~b} 2, \mathrm{~b} 3=\text { Koefisien regresi } \\
& \varepsilon \mathrm{i}=\text { Error term (variabel pengganggu) }
\end{aligned}
$$

\section{Uji Koefisien Determinasi $\left(\mathbf{R}^{2}\right)$}

Menurut Ghozali (2012:97) koefisien determinasi $\left(\mathrm{R}^{2}\right)$ merupakan alat untuk mengukur seberapa jauh kemampuan model dalam menerangkan variasi variabel dependen. Nilai koefisien determinasi $\left(\mathrm{R}^{2}\right)$ adalah antara 0 atau 1.

\section{Uji Hipotesis}

a. Uji t

Menurut Ghozali (2013:98) uji ini digunakan untuk mengetahui apakah variabel independen Persepsi Masyarakat (X) berpengaruh secara signifikan terhadap variabel dependen Pelayanan Frontliner (Y). b. Uji F

Menurut Ghozali (2013:98) uji F pada dasarnya menunjukkan apakah semua variabel independen atau bebas yang dimasukkan dalam model mempunyai pengaruh secara bersamasama terhadap variabel dependen atau terikat. Pada pengujian ini juga menggunakan tingkat signifikansi sebesar 5\% atau 0,05.

Perhitungan model analisis regresi linear berganda di atas, menggunakan alat bantu program lunak komputer (software) SPSS.

\section{Uji Asumsi Klasik}

Suatu pengujian asumsi klasik atas data yang akan diolah sebagai berikut :

a. Uji Normalitas

Uji normalitas bertujuan untuk menguji apakah dalam model regresi, variabel pengganggu atau residual memiliki distribusi normal. Untuk menguji apakah data berdistribusi normal atau tidak dilakukan uji statistik Kolmogorov-Smirnov Test. Residual berdistribusi normal jika memiliki nilai signifikansi >0,05 (Ghozali, 2011: 160-165). b. Uji Multikolinieritas

Uji multikolinieritas bertujuan untuk menguji apakah model regresi ditemukan 
adanya korelasi antar variabel bebas (independen). Untuk menguji multikolinieritas dengan cara melihat nilai VIF masing-masing variabel independen, jika nilai $\mathrm{VIF}<10$, maka dapat disimpulkan data bebas dari gejala multikolinieritas (Ghozali,2011: 105-106).

c. Uji Heteroskedastisitas

Uji heterokedastisitas bertujuan menguji apakah dalam model regresi terjadi ketidaksamaan variance dari residual satu pengamatan ke pengamatan yang lain. Ada beberapa cara yang dapat dilakukan untuk melakukan uji heteroskedastisitas, yaitu uji grafik plot, uji Park, uji Glejser, dan uji White. (Ghozali, 2011: 139-143).

\section{HASIL DAN PEMBAHASAN}

\subsection{Hasil Penelitian}

\subsubsection{Uji Validitas}

Berdasarkan hasil uji validitas diperoleh interpretasi atas uji validitas data di atas adalah semua pertanyaan dinyatakan valid karena semua indikator pada tabel diatas memiliki nilai $r$ hitung lebih besar dari $r$ tabel didapat dari 100 responden dengan taraf signifikansi 5\% atau 0.05 diperoleh nilai sebesar 0,1966 dan mampu untuk mengukur dan mampu untuk mengukur persepsi nasabah terhadap pelayanan frontliner.

\subsubsection{Uji Reliabilitas}

Tabel 4.1. Hasil Uji Reliabilitas

\begin{tabular}{cr}
\hline Cronbach's Alpha & N of Items \\
\hline \multicolumn{1}{c}{.883} & 34 \\
\hline Sumber : Hasil Olahan SPSS (2018)
\end{tabular}

Berdasarkan angka Cronbach's Alpha sebesar 0,883 lebih besar dari 0,6 maka instrumen yang digunakan (kuesioner) dapat dinyatakan reliabel alasannya karena jawaban dari responden terhadap pertanyaan adalah konsisten atau stabil dari waktu ke waktu.

\subsubsection{Analisis Regresi Linear Sederhana}

Hasil analisis regreasi linear berganda diperoleh seperti tampak dalam tabel 4.2 berikut :

Tabel 4.2. Hasil Regresi Linear Berganda

\begin{tabular}{|c|c|c|c|c|c|c|}
\hline & \multirow[b]{2}{*}{ Model } & \multicolumn{3}{|r|}{$\begin{array}{c}\text { Standardi } \\
\text { zed } \\
\text { Coefficie } \\
\text { nts } \\
\end{array}$} & \multirow[b]{2}{*}{$\mathrm{t}$} & \multirow[b]{2}{*}{ Sig. } \\
\hline & & $\mathrm{B}$ & $\begin{array}{c}\text { Std. } \\
\text { Error }\end{array}$ & Beta & & \\
\hline \multirow[t]{4}{*}{1} & (Constant) & 16.856 & 4.222 & & 10.15 & .000 \\
\hline & Sikap & .773 & .484 & .508 & 5.72 & .000 \\
\hline & Motivasi & .479 & .152 & .381 & 7.11 & .000 \\
\hline & Pengalaman & .295 & .477 & .236 & 2.71 & .008 \\
\hline
\end{tabular}

Sumber: Hasil Olah Data (2018)

Dari hasil regresi linear berganda di atas, maka dapat dinyatakan dalam persamaan sebagai berikut:

$\mathrm{Y}=16.856+0.773 \mathrm{X}_{1}+0.479 \mathrm{X}_{2}+0.295 \mathrm{X}_{3}$

Dari model persamaan regresi linear berganda tersebut ditemukan hubungan positif dan signifikan antara sikap, motivasi dan pengalaman masa lalu terhadap pelayanan frontliner. Sehingga dapat diinterprestasikan sebagai berikut:

Koefisien regresi $\left(\mathrm{X}_{1}, \mathrm{X}_{2}, \mathrm{X}_{3}\right)$ terhadap variabel Y (Pelayanan frontliner) pada BPR TLM menunjukkan nilai positif dan signifikan. Variabel persepsi berdasarkan sikap bernilai sebesar 0.773 atau $77.3 \%$ yang berarti jika setiap penambahan 1 satuan nilai persepsi berdasarkan sikap maka nilai pelayanan frontliner bertambah sebesar 0.773 .

Variabel persepsi berdasarkan motivasi bernilai sebesar 0.479 atau $47.9 \%$ yang berarti jika setiap penambahan 1 satuan nilai persepsi berdasarkan motivasi maka nilai pelayanan frontliner bertambah sebesar 0.479 .

Variabel persepsi berdasarkan pengalaman masa lalu bernilai sebesar 0.295 atau $29.5 \%$ yang berarti jika setiap penambahan 1 satuan nilai persepsi berdasarkan pengalaman masa lalu maka nilai pelayanan frontliner bertambah sebesar 0.295. 


\subsubsection{Uji Asumsi Klasik}

a. Uji Normalitas

Hasil Uji normalitas dengan menggunakan uji statistik KolmogorovSmirnov Test. Residual berdistribusi normal jika memiliki nilai signifikansi >0,05 (Ghozali, 2011: 160-165).

Diuji dengan menggunakan kolmogorov smirnov test yang ditunjukkan tabel 4.3 berikut :

\begin{tabular}{llc} 
& \multicolumn{2}{c}{ Tabel 4.3. Uji Normalitas } \\
\hline & & Unstandardized Residual \\
\cline { 3 - 3 } $\mathrm{N}$ & Mean & 100 \\
\hline & Std. & .0000000 \\
& Deviation & 3.03601351 \\
& Absolute & .060 \\
& Positive & .060 \\
& Negative & -.057 \\
Kolmogorov- & Mean & \\
Smirnov Z & & .602 \\
& Std. & \\
Asymp. Sig. & Deviation & \\
(2-tailed) & & .862 \\
\hline
\end{tabular}

Sumber: Hasil Olah Data (2018)

Dari tabel 4.3, diketahui bahwa sig. (2tailed) sebesar 0.862 atau $0.862>0.05$ sehingga dapat dikatakan bahwa data berdistribusi normal.

\section{b. Uji Multikolinieritas}

Untuk menguji multikolinieritas dengan cara melihat nilai VIF masing-masing variabel independen, hasil uji multikolinieritas tampak pada tabel 4.4 , berikut :
Tabel 4.4 Uji Multikolinieritas

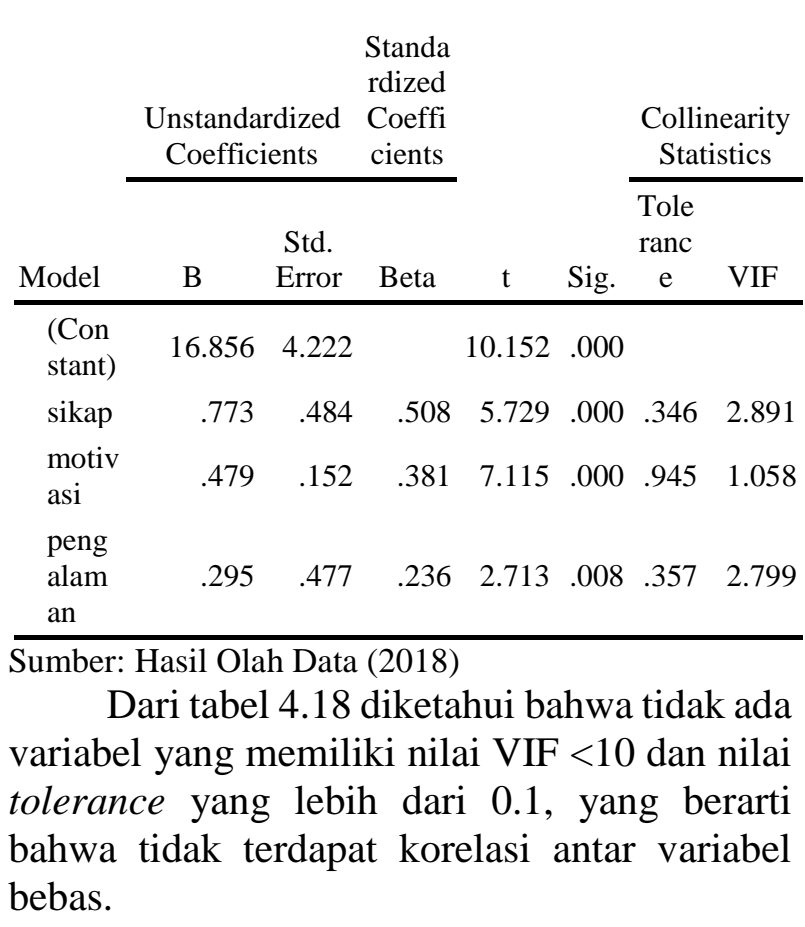

\section{c. Uji Heteroskedastisitas}

Hasil Uji heteroskedastisitas dapat diketahui bahwa jika titik-titik data menyebar di atas dan di bawah titik 0 (nol) pada sumbu Y dan $\mathrm{X}$, maka dapat disimpulkan bahwa tidak terjadi gejala heteroskedastisitas.

\subsubsection{Koefisien Determinasi (R Square)}

Hasil Koefisien determinasi $\left(\mathrm{R}^{2}\right)$ adalah seperti tampak pada tabel 4.5, berikut

Tabel 4.5. Hasil Regresi Linear Berganda

\begin{tabular}{|c|c|c|c|c|}
\hline Model & $\mathrm{R}$ & $\begin{array}{c}\mathrm{R} \\
\text { Square }\end{array}$ & $\begin{array}{l}\text { Adjusted R } \\
\text { Square }\end{array}$ & Std. Error of the Estimate \\
\hline 1 & $\begin{array}{r}.860 \\
\mathrm{a}\end{array}$ & .739 & .731 & 3.08309 \\
\hline
\end{tabular}

Sumber: hasil olah data, 2018

Dari tabel perhitungan tabel 4.5, diketahui nilai koefisien determinasi $(R$ Square) sebesar 0.731. Besarnya angka koefisien determinasi ( $R$ Square) 0.731 sama dengan $73.1 \%$. Angka tersebut mengandung arti bahwa persepsi nasabah berpengaruh terhadap pelayanan frontliner sebesar $73.1 \%$, 
sedangkan sisanya $26.9 \%$ dipengaruhi oleh variabel lain diluar model regresi ini, seperti lamanya antrian atau proses peminjaman dan penyimpanan uang.

\subsection{Pembahasan Hasil Penelitian}

Dari hasil penelitian, setiap variabel independen yaitu sikap, motivasi dan pengalaman masa lalu menunjukkan pengaruh yang positif dan signifikan terhadap variabel dependen yaitu pelayanan frontliner. Variabel sikap menunjukkan hubungan yang positif dan signifikan dengan pelayanan frontliner. Hal ini menunjukkan bahwa pelayanan frontliner yang diberikan petugas frontliner telah memenuhi ekspektasi atau harapan dari nasabahnya.

Untuk variabel motivasi menunjukkan hubungan yang positif dan signifikan dengan pelayanan frontliner. Hal ini menunjukkan bahwa pelayanan frontliner pada BPR TLM menjadi salah satu poin penting dalam menarik nasabah, karena jika petugas frontliner yang berhubungan langsung tidak bersikap ramah ataupun berpenampilan rapi dan bersih maka nasabahpun dapat menilainya negatif, tetapi apabila petugas frontliner melayani dengan ramah dan menghargai nasabahnya, maka nasabah akan merasa nyaman dan akan terus bertransaksi.

Untuk variabel pengalaman masa lalu menunjukkan hubungan yang positif dan signifikan dengan pelayanan frontliner. Hal ini menunjukkan bahwa pelayanan frontliner memiliki reputasi baik disekitar masyarakat sehingga menjadi salah satu BPR TLM yang paling diminati oleh masyarakat.

Dari hasil penelitian, pengaruh secara keseluruhan dari variabel independen yaitu sikap, motivasi dan pengalaman masa lalu menunjukkan pengaruh yang positif dan signifikan terhadap variabel dependen yaitu pelayanan frontliner. Artinya, tiap aspek dalam persepsi nasabah dapat mempengaruhi pelayanan yang diberikan oleh petugas frontliner, dalam hal ini berdasarkan sikap, motivasi dan pengalaman masa lalu terhadap pelayanan frontliner pada BPR TLM.

Dari hasil kuesioner yang dilakukan di BPR TLM sesuai dengan teori persepsi yaitu persepsi pada hakikatnya adalah proses kognitif yang dialami oleh setiap orang di dalam memahami informasi tentang lingkungannya baik lewat penglihatan, pendengaran, penghayatan, perasaan, dan penciuman (Thoha1983:144).

Terdapat beberapa hal yang dapat mempengaruhi persepsi nasabah terhadap BPR TLM yaitu:

a. Sikap

Merupakan poin yang dapat mempengaruhi positif atau negatifnya tanggapan yang akan diberikan seseorang. Sikap berhubungan langsung secara fisik yang berarti gestur badan maupun mimik wajah yang dapat langsung dilihat. Persepsi nasabah berdasarkan sikap pada pelayanan yang diberikan petugas frontliner di BPR TLM, menunjukkan bahwa nasabah merasa senang dan puas dengan pelayanan yang diberikan, karena petugas frontliner melayani setiap nasabah dengan baik dan selalu tersenyum dengan ramah serta selalu berpenampilan bersih dan rapi, sehingga nasabah pun menjadi nyaman untuk bertransaksi di BPR TLM.

b. Motivasi

Merupakan hal yang mendorong seseorang mendasari sikap tindakan yang dilakukannya. Motivasi dapat dipengaruhi oleh lingkungan seperti keluarga maupun orang terdekat dalam mengambil sebuah tindakan. Persepsi nasabah berdasarkan motivasi pada pelayanan yang diberikan petugas frontliner di BPR TLM, menunjukkan bahwa sebagian besar nasabah mendapat rekomendasi dari keluarga dan teman mereka ataupun berdasarkan keinginan sendiri untuk menabung 
di BPR TLM, karena mereka merasa aman dan mempercayai kualitas dan mutu pelayanan yang diberikan oleh BPR TLM, dan itu tidak terlepas dari petugas frontliner yang telah melayani setiap nasabahnya dengan baik

c. Pengalaman Masa Lalu

Mempengaruhi persepsi seseorang karena biasanya akan menarik kesimpulan yang sama dengan apa yang pernah dilihat dan didengar. Jika orang tersebut mempunyai pengalaman yang baik atau tidak, dapat mempengaruhi orang tersebut dalam berpendapat. Persepsi nasabah berdasarkan pengalaman masa lalu pada pelayanan yang diberikan petugas frontliner di BPR TLM, menunjukkan bahwa nasabah memilih untuk menabung pada BPR TLM dikarenakan mereka merasa pelayanan yang diterima di BPR TLM lebih nyaman dan baik dibandingkan dengan pengalaman para nasabah di bank atau pelayanan jasa keuangan lainnya, sehingga para nasabah merasa puas saat melakukan transaksi di BPR TLM.

BPR TLM selalu ingin memberikan yang terbaik kepada para nasabahnya. Persepsi nasabah sangat berpengaruh terhadap peningkatan kualitas BPR TLM terkhususnya untuk petugas frontliner, karena dapat menjadi tolak ukur bagi para petugas frontlinernya untuk lebih meningkatkan lagi pelayanan di BPR TLM. Hal ini sejalan dengan penelitian sebelumnya yang dilakukan oleh Santika (2016) yang mengatakan bahwa persepsi dari nasabah dapat mempengaruhi kinerja dan kualitas dari petugas frontliner.

Dihubungkan dengan teori menurut Parasuraman, Zeithaml \& Berry (2006:19) untuk mengukur baik tidaknya pelayanan diketahui dengan melakukan perbandingan antara pelayanan yang dirasakan (persepsi) konsumen (nasabah) dengan pelayanan yang diharapkan konsumen (nasabah). Jika pelayanan yang dirasakan sama atau melebihi pelayanan yang diharapkan maka pelayanan dikatakan atau dipersepsikan berkualitas dan memuaskan, namun apabila yang terjadi sebaliknya, maka pelayanan tersebut dikatakan atau dipersepsikan negatif atau tidak berkualitas.

Hasil kuesioner menunjukkan bahwa persepsi nasabah positif terhadap pelayanan frontliner, pelayanan yang baik akan menyenangkan dan meningkatkan nasabah. Terdapat beberapa poin untuk mengukur baik tidaknya suatu pelayanan dirangkum menjadi 5 dimensi pokok, yaitu sebagai berikut:

Bukti langsung, yaitu meliputi fasilitas fisik yang dimiliki seperti gedung dan lahan parkir; pegawai seperti seragam yang dikenakan; dan sarana komunikasi. BPR TLM berlokasi di tempat yang mudah dijangkau dan mempunyai ruang tunggu yang nyaman. Petugas frontlinerpun berpenampilan rapi dan bersih.

Keandalan, yakni kemampuan para pegawai dalam memberikan pelayanan yang dijanjikan dengan segera, akurat, dan memuaskan. Pelayanan petugas frontliner (teller) dalam melayani setor tunai dan tarik tunai dilakukan dengan baik dan cepat sehingga nasabah tidak perlu menunggu antrian lebih lama. Pemberian informasi produk oleh petugas frontliner (customer service) dinilai baik oleh nasabah.

Daya tanggap, yaitu keinginan para pegawai untuk membantu para pelanggan dan memberikan pelayanan dengan tanggap. Petugas frontliner menanggapi dan menjawab permintaan atau pertanyaan dari nasabah masih ada yang dinilai belum maksimal, terutama pada pemberian solusi terhadap masalah atau keluhan yang dialami nasabah.

Jaminan, mencakup pengetahuan, kemampuan, kesopanan, dan sifat dapat dipercaya yang dimiliki para pegawai, bebas dari bahaya, resiko atau keragu-raguan. 
Keamanan bertransaksi merupakan poin penting bagi nasabah dikarenakan, jika transaksi yang dilakukan berjalan baik dan data dari nasabah dijaga baik oleh petugas BPR TLM, maka nasabah akan terus melakukan transaksi di BPR TLM.

Empati, yaitu para pegawai memberikan kemudahan kepada nasabah dalam melakukan hubungan, komunikasi yang baik, perhatian pribadi, dan memahami kebutuhan tiap nasabahnya. Keramahan yang ditunjukkan oleh para petugas frontliner merupakan salah satu poin penting dalam pelayanan, dikarenakan jika petugas melayani nasabah dengan ramah dan penuh senyum, maka nasabah pun akan merasa senang dan nyaman untuk melakukan transaksi.

Dari kelima dimensi pokok diatas yang menjadi standar bagi petugas frontliner BPR TLM untuk memberikan pelayanannya kepada nasabah. Sehingga dengan demikian dapat menjadi dorongan bagi nasabah untuk terus melakukan transaksi di BPR TLM. Hal ini sejalan dengan penelitian sebelumnya yang dilakukan oleh Juairiah (2016).

Dari hasil wawancara, persepsi nasabah berpengaruh positif, karena pelayanan yang diberikan petugas frontliner sesuai dengan yang diharapkan oleh nasabah. Pelayanan yang diberikan dinilai semakin membaik setiap tahunnya. Tutur kata yang ramah, perilaku yang sopan dan dapat berinteraksi dengan baik membuat nasabah merasa nyaman bertransaksi di BPR TLM. Selain itu nasabah juga merasa senang dengan penyediaan ruang tunggu yang nyaman dan lokasi BPR TLM yang mudah dijangkau baik dengan menggunakan kendaraan umum maupun kendaraan pribadi.

Dari sudut pandang ekonomi perbankan, BPR memiliki perbedaan dengan Bank Umum, karena BPR lebih memfokuskan pelayanan pada masyarakat menengah kebawah atau masyarakat yang mengalami kesulitan akses untuk menabung di bank umum serta kepada para wirasawasta, usaha mikro dan kecil, dengan memberikan produk-produk barang dan jasa yang memudahkan nasabah melakukan transaksi baik itu menabung maupun pinjaman kredit dengan persyaratan yang mudah. BPR TLM sesuai dengan visi dan misinya yaitu menjadi bank yang sehat dan terpercaya serta peduli akan usaha mikro dan kecil, menunjukkan bahwa BPR TLM ingin memberikan pelayanan terbaik mereka bagi masyarakat kecil dengan jujur dan membantu memberikan pinjaman bagi masyarakat yang memiliki usaha mikro dan kecil agar dapat berkembang.

Dari pembahasan ini dapat disimpulkan bahwa pelayanan dari petugas frontliner yang diterima oleh nasabah dapat mempengaruhi penilaian dan pemahaman nasabah terhadap petugas frontliner BPR TLM. Pelayanan yang terbaik dapat memberikan kepuasan bagi kedua belah pihak yaitu nasabah dan pihak BPR TLM, dengan menerima kritik dan saran yang diberikan nasabah terhadap pelayanan petugas frontliner sehingga lebih dapat meningkatkan kualitas pelayanan yang diberikan, karena sikap dan perilaku yang ditunjukkan oleh para pegawai BPR TLM terutama petugas frontliner menunjukkan kualitas BPR TLM sendiri. Jika pelayanan yang diberikan sesuai dengan yang diharapkan oleh nasabah, maka transaksi yang dilakukan dalam BPR TLM pun dapat berjalan dengan lancar.

\section{KESIMPULAN, KETERBATASAN DAN SARAN}

\subsection{Kesimpulan}

Berdasarkan hasil analisis yang dapat disimpulkan bahwa:

1. Pengaruh persepsi nasabah berdasarkan sikap terhadap pelayanan frontliner adalah positif. Nasabah puas akan rasa hormat dan menghargai yang ditunjukkan oleh petugas 
frontliner BPR TLM selama terjadinya transaksi.

2. Pengaruh persepsi nasabah berdasarkan motivasi terhadap pelayanan frontliner adalah positif. Sebagian besar orang yang menjadi nasabah pada BPR TLM karena mendapat banyak rekomendasi dari lingkungan sekitar ataupun kerabat dekat.

3. Pengaruh persepsi nasabah berdasarkan pengalaman masa lalu terhadap pelayanan frontliner adalah positif. sebagian besar nasabah mengaku menjadi nasabah BPR TLM karena mempunyai reputasi yang baik dan memiliki produk-produk yang berkualitas, dan petugas frontliner BPR TLM melayani transaksi setor maupun tarik tunai dengan baik dan cepat serta menjaga kerahasiaan data nasabah dan membuat nasabah merasa aman dan nyaman selama bertransaksi di BPR TLM.

\subsection{Keterbatasan dan Saran}

Dari pembahasan dan kesimpulan diatas, maka saran yang dapat diajukan penulis adalah sebagai berikut:

1. Pengaruh persepsi nasabah berdasarkan sikap terhadap pelayanan frontliner adalah indikator yang paling berpengaruh dalam nasabah melakukan persepsi.

2. Pengaruh persepsi nasabah berdasarkan motivasi terhadap pelayanan frontliner juga mempengaruhi persepsi nasabah dan diharapkan bagi petugas frontliner BPR TLM untuk dapat mempertahankan kualitas pelayanan yang diberikan saat ini dan setiap kritikan saran yang para nasabah berikan bisa membuat BPR TLM dapat berkembang menjadi lebih baik lagi.

3. Pengaruh persepsi nasabah berdasarkan pengalaman masa lalu terhadap pelayanan frontliner, reputasi yang baik dikalangan masyarakat dan nasabah, harus dipertahankan oleh BPR TLM dan lebih meningkatkan baik sarana maupun prasarana untuk lebih memudahkan nasabah melakukan transaksi.

\section{DAFTAR PUSTAKA}

Ariesto Hadi Sutopo dan Adrianus Arief.2010. Terampil Mengolah Data Kualitatif Dengan NVIVO. Jakarta: Kencana Prenada Media Group

Assauri, Sofjan.1999. Manajemen Pemasaran: Dasar, Konsep dan Strategi. Jakarta: PT. Raja Grafindo Persada

Authar Mohammad Nailul.2017. Implementasi Standar Pelayanan Frontliner PT. Panin Bank Syariah Tbk. Cabang Malang.Malang: Fakultas Ekonomi Universitas Islam Negeri

Ghozali, Imam. 2005. Aplikasi Analisis Multivariate dengan Program SSPS.

Semarang :Penerbit Universitas Diponegoro.

Hasibuan Malayu. 2011. Dasar-dasar Perbankan. Jakarta: Bumi Aksara

Juariah.2016. Pengaruh Kualitas Layanan Frontliner Terhada Tingkat Kepuasan Pelayanan Nasabah Pada Pt. Bank Sumselbabel Syari'ah Cabang Palembang.Palembang: Fakultas Ekomoni dan Bisnis UMPalembang

Kasmir. 2002. Dasar-dasar Perbankan. Jakarta : PT. Raja Grafindo 2006.Dasar-dasar Perbankan.Jakarta : PT. Raja Grafindo

Kotler, Philip. Manajemen Pemasaran, Jilid 1, PT. Indeks Kelompok Gramedia, Jakarta.2005

Moenir A.S.2010.Manajemen Pelayanan Umum di Indonesia.Jakarta: Bumi Aksara

Muslimah, Sonny Koeswara.2014. Analisis Pengaruh Kinerja Pelayanan Frontliner Dan Kepuasan Nasabah Dengan Pendekatan Metode Regresi 
Linear Multiple.Jakarta: Program Studi Teknik Industri Fakultas Teknik Universitas Mercu Buana

Parasuraman, A., Zeithaml, V.A. dan Berry, L.L,2006. Pelayanan Pelanggan yang sempurna, Kunci ilmu.Yogyakarta

Rahmat Jalaluddin, 2003. Psikologi Komunikasi.Bandung: Remaja Rosdakarya

Robbins Stephen, Timothy A. Judge.2009.Perilaku Organisasi edisi 12.Jakarta: Salemba Empat

Roviana Eva.2015. Analisis Pengaruh Persepsi Harga Atau Margin Dan Kualitas Pelayanan Terhadap Minat Anggota Dalam Membeli Produk Pembiayaan Murabahah Di Koperasi Jasa Keuangan Syariah (Studi Kasus Bmt Amal Mulia).Salatiga: Jurusan Syariah Dan Ekonomi Islam Sekolah Tinggi Agama Islam Negeri (STAIN)

Sugiyono. 2014. Metode Penelitian Kombinasi (Mixed Methods), Bandung: Alfabeta

Sutopo Ariesto Hadi, Adrianus Arief, 2010. Terampil Mengolah Data Kualitatif Dengan NVIVO.Jakarta: Kencana Prenada Media Group

Tjiptono Fandy.2008. service manajement. Yogyakarta: Penerbit Andi

Thoha Miftah.1983. Perilaku Organisasi Konsep Dasar Dan Aplikasinya. Jakarta: PT Raja Grafindo,)

Santika Dewi.2016. Analisis Persepsi Nasabah Terhadap Kualitas Pelayanan Bank Perkreditan Rakyat Di Pontianak Dan Sekitarnya.Pontianak: STIE Widya Dharma Pontianak

Sedarmayanti.2009. Reformasi Administrasi Publik, Reformasi Birokrasi, dan Kepemimpinan Masa Depan (Mewujudkan Pelayanan Prima dan Kepemerintahan yang Baik). Bandung : Refika Aditama
Setiadi, Nugroho J. 2003. Perilaku Konsumen. Jakarta: Kencana

Silalahi Ulber.2017.Metode Penelitian Sosial Kuantitatif.Bandung: PT. Refika Aditama

Sinambela, Lijan Poltak. Dkk.2011 .Reformasi Pelayanan Publik. Jakarta: Bumi Aksara

Supranto, J.1997. Pengukur Tingkat Kepuasan

Pelanggan. Jakarta : Rineka Cipta .2006. Pengukuran Tingkat Kepuasan Pelanggan Cetakan Ketiga.Jakarta: Rineka Cipta .2006. Pengukur Tingkat Kepuasan Pelanggan Untuk Meningkatkan Pangsa Pasar. Jakarta : Rineka Cipta.

Veithzal Rivai.2002.Kepemimpinan Dan Perilaku Organisasi. Jakarta: PT Raja Grafindo Persada,)

Walgito Bimo.2002.Pengantar Psikologi Umum.Yogyakarta: Andi Offset

http://www.ojk.go.id/id/kanal/perbankan/Page s/Bank-Perkreditan-Rakyat.aspx

http://www.jdih.kemenkeu.go.id/fullText/1998 /10Tahun 1998UU.htm 